reticularis, and strike against the under surface of the membrana tecloria. A reaction would take place from the latter, and thus the delicate nerve-endings between the hair-cells would receive pressures corresponding in frequency to the oscillations of the membrana basilaris. In the cochlea of birds and amphibia, the mechanism is practically the same, but in consequence of the membrana basilaris not being highly differentiated, there cannot be the nice discrimination of pitch of tone which exists in the higher animals. The lecturer gave reasons for holding that a bird has a power of discriminating pitch only through at narrow range. These views were also, on the whole, supported by pathological observations in cases of deafness, and of the deaf ness of boiler-makers in particular. In the latter there is the loss of perception of high tones, and degenerations are observed in the lower whorl of the cochlea, as is required loy theory. The action of the cochlea, as thus conceived, was demonstrated with a model. The lecturer also gave a large number of measurements of parts of the ear, showing that there were a sufficient number of structures in the cochlea to enable us to detect differences of the $1 / 64^{\text {th }}$ of a semitone, thus amplifying the conclusions reached long ago by Helmholtz. The number of nerve-fibres in each cochlear division of the auditory nerve is about 14,000, giving something like 1250 for each octave through the eleven octaves of audibility. Assuming that the number of auditory filaments is the same for each of the eleven octaves (an unlikely supposition, as there will probably be a larger number of filaments for octaves in the middle of the range of the ear), there will still be two filaments for each $1 / 64$ th of a semitone; while, for the same interval, there will be three fibres of the membrana basilaris, and two hair-cells. The production of combination tones, differential and summational, was next considered, the lecturer stating that, in his opinion, and founded on experiment, both had an objective existence. They are not beats, but true sounds superadded to the generators, and thus they fall within the scope of Ohm's law. The theories, other than that of Helmholtz, were then criticised; namely, those of Rutherford, Waller, Hurst, and the more recent one of Max Mayer. The most obvious objection to any theory which dis penses with peripheral analysis is that it leaves the exceer ingly elaborate structure of the organ of Corti, and indeed of the cochlea, as a whole, out of account ; or, to put the matter in another light, it assigns to that organ a comparatively simple function. Ohn's law also may be subject to certain limitations, but there is no substitute for it. Max Mayer agrees with Hurs in imagining a series of waves transmitted along the scalæe, instead of the scalæ forming part of one wave. The two diffe in respect that Max Mayer supposes, on physical grounds, that the amplitude must diminish from base to apex of the cochlea; while Hurst argues, also from the physical poin of view, that the amplitude nust increase. This is a serious discrepancy, inasmuch as Mayer's theory rests wholly on the supposition of diminished amplitude. It seems impossible to conceive of minute waves following each other in rapid succession in the minute tubes forming the scale. These theories are independent of the principle of sympathetic resonance, imperishably associated with the name of Helmholtz, and which still, in the lecturer's opinion, holds the field. Lastly, the lecturer pointed out that the roots of the auditory nerves were probably more widely distributed and had more extensive connections than those of any other nerve. The intricate connections of these nerves were only being unravelled. This pointed to an explanation of how music penetrates to the very roots of our being, influencing by associational paths, reflex mechanisms, both cerebral and somatic, so that there was scarcely a function of the body that might not be affected by the rhthymic pulsations, melodic progressions, and harmonic combinations of musical tones.

\section{THE DARMSTADT MUSEUM.}

THROUGHOUT the civilised world attention is being concentrated on the improvements in the mode of arranging specimens in the exhibition galleries of natural history museums ; so that they should be both attractive and instructive to the general public, and at the same time useful to the student. Nowhere does this advance seem more marked than at Darmstadt, where the Director, Dr. G. von Koch, has just published an interesting and well illustrated progress report ("Die Aufstellung der Tiere im neuen Museum zu Darmstadt," Leipsic, I899.)

NO. I 546 , VOL. 6o]
We gather from this report that a large proportion of the muselum is devoted to the systematic classification of animals and it is gratifying to observe that not only are skeletons and skulls ranged side by side with the mounted skins, but that anatomical preparations and remains of extinct forms are in troduced in their proper serial position. A notable feature (in the seventh gallery) is the exhibition of a series of economic animal products, such as furs, wool, leather, ivory, tortoiseshell, mother-of-pearl, shell, coral, \&c. But the greatest novelty is the formation of a gallery (the eighth in the series) illustrating the geographical distribution of animals on the globe. And here, instead of arranging the specimens on the conventional wooden stands on tier upon tier of shelves, an attempt has been made to reproduce the natural surroundings of their habitat.

To take, for example, the South and Central American region, we find, as shown by one of the plates accompanying the report, alligators, tapirs, carpinchos, chajas, \&c., uccupying the low land by the river. In the adjacent forest tract we have anteaters, sloths, coatis, pacas, opossums, armadillos and the characteristic monkeys. On a higher level we have the open pampas and llanos, with peccaries, brockets, pumas and rheas; while the background of the scene is formed by mountain peaks tenanted by guanacos, vicugnas and condors. Birds of other kinds are likewise introduced in appropriate positions so far as the limits of space permit. Similar scenes represent the other great zoo-geographical regions; and it is important to notice that the whole series is ushered in by the fauna of Hessen-Darmstadt itself.

It would undoubtedly add much to the interest and instructiveness of our own natural history museums if arrangements could be made for the formation of galleries of economic and distributional zoology on somewhat similar lines.

\section{UNIVERSITY AND EDUCATIONAL INTELLIGENCE.}

OXFORD.-A number of the foreign guests who had been present at the Stokes jubilee celebration and the Royal Institution centenary were invited to Oxford on the 8th, and were entertained at a luncheon in Christ Church. Among those who came were Profs. Arrhenius, Barker, Barus, Becquerel, Bleekrode, Ciamician, Cornu, Deslandres, Franchimont, Egoroff, Gautier, Körner, Le Chatelier, Liebreich, Martius, Michelson, Moissan, Nasini, Newcomb, and Sivewright.

In a convocation held the same day, the honorary degree of D.C.L. was conferred upon Profs. Becquerel, Körner, Lie breich, Moissan and Newcomb.

The following were the speeches made by the Regius Professor of Civil Law, Dr. H. Goudy, in presenting them.

Nihil puichrius nobisque optatius est quam viros e gentibus externis de scientiarum studiis optime meritos societati nostrae adscribi atque arctissimo et dignitatis et amicitiae nobiscum vinculo consociari. Quae res hodie Universitati nostrae contigit quae eos viros, quos mihi adstare videtis, communi omnium ejus membrorum consensu (Instituti quod dicitur Regii annum centenarium feliciter actum commemorans) insigniri jussit.

\section{BF.CQUEREL.}

Primum ad vos duco virum illustrem, Gallica stirpe oriundum, qui in scientia physicae famam eximiam est adeptus, patris in eadem scientia illustris filius. Physicae studiosorum in mani bus sunt scripta ejus praeclara principiis scientiae illius illustrandis destinata. Operum numerum quorum auctor doctus ille exstitit referre longum est; neque tamen, ut plurima praeteream, silentio praetereunda videntur opuscula illa, publici juris facta, in quibus de magnetis et electri proprietatibus felicissime disseruit, ipsamque Naturam, rerum creatricem, in lucem proferre coegit quanam ratione quaedam corpora aliquando lumina emittant atque vires electricas eis transmissas per longum tempus retinere possint.

\section{KÖRNER.}

Praesento vobis virum egregium, Germanica stirpe oriundum, inter eos qui praecipuan curam rebus chemicis dederunt notissimum. Quantum in ea parte Naturae profecerit, quam multa ingeniose et subtiliter excogitaverit, mihi exponere minime concedit sermonis academici egestas! Quid de compositis

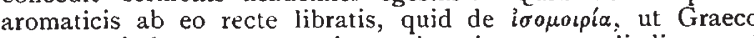
utar vocabulo, corporum in conjunctione naturali disseram? 
Audisse sit satis kunc de his studiis ita meritum ut omnibus inter nostrates qui se iisdem studiis maxime devoverint dignus omnimodo laureâ nostrâa videatur.

\section{LIEBREICH.}

Salutamus deinceps virum e finibus Germaniae insignem. Ille secreta cerebri feliciter rimatus ad ipsa materiae atoma penetrando phosphorum capitalem Phosphorus et Lucifer ipse clarissimus nobis primo patefecit. Idem acerbissimos animi corporisque dolores impune extinxit,

Spargens chlora venena soporiferumque papaver.

Immo somnum insomnibus attulit, mollem, mortique simillimum.

\section{Moissan.}

Praesento vobis virum illustrem Lutetiis Parisiorum pro fessorem. Viri hujus ingenium illustre, diligentiam, eru ditionem in ea scientia quam ad illustrandam unice se devovit, jamdiu confessi sunt qui eadem in re florentissimi extiterunt Sed nomini suo immortalitatem quandam justissimo titulo meruisse videtur, invento uno scientiae suae utilissimo; scilicet Fluorii elementum segregando, id quod nulli ante facere contigit, neque sine vitae periculo prioribus constabat experimentum hujusmodi; (scilicet qui sese ante nostrum experimento huic dedicaverant, duo, ante victoriam partan, occubuerunt, lauream tamen reportavit noster, periculo superstes atque, utinam diu superstes sit !)

\section{NEWCOMB.}

Sequitur deinceps vir insignis qui trans fluctus Atlanticos transvectus ad nos venit-senex antistes Naturae. Hunc virum scitote per multos annos astrorum motus rationemque coeli ita ingeniose perscrutatum fuisse ut multa non solum nova reperiat sed etiam sermone dilucido expressa argumentis confirmaret certissimis. Idem luminis velocitatem et quantum sol ab orbe terrarum distet singulari curâ investigavit, et tabulas Lunae motus correxit.

"Scire juvat magni penitus praecordia mundi."

At the Encænia, on June 2I, the honorary degree of D.C.L. will be conferred upon the Earl of Elgin, Lord Kitchener, Sir Charles Parry, F. W. Maitland, F. D. Godman, Father Ehrle, Cecil Rhodes, and J. G. Frazer.

The eleventh annual report of the delegates of the Uni versity Museun (for 1898 ) is published in the Universily Gazette for June 6. This publication, which increases in dimensions every year, contains the reports of the Regius Pro fessor of Medicine, the Linacre Professor of Comparative Anatomy, the Waynflete Professor of Physiology, the Professor of Human Anatomy, the Hope Professor of Zoology, the Pro fessor of Experimental Philosophy, the Waynflete Professor of Chemistry, the Professor of Geology, and the Waynflete Professor of Mineralogy, and records substantial progress in al these departments.

Mr. E. S. Goodrich has been re-appointed Aldrichian Demonstrator of Anatomy.

Dr. J. F. Payne has been elected a member of the Medical Council of the United Kingdom, in place of Dr. W. S. Church, resigned.

Scholarships in Natural Science are advertised at the following Colleges :-Balliol, November 21; Merton, June 27 New, June 27 ; Magdalen, October Io ; Corpus Christi, June 27 ; Christ Church, November 21 ; Trinity, November $2 \mathrm{I}$.

On June I4, a statue of Charles Darwin, by Mr. Hope Pinker, which has been presented to the University by Prof. Poulton, will be inaugurated at the University Museum.

Cambridge.-Mr. H. M. MacDonald, of Clare College, fourth Wrangler 1889 , has been appointed University Lecturer in Mathenatics in place of Prof. Love, now of Oxford.

Mr. A. E. Shipley, of Christ's College, has been re-appointed University Lecturer in Invertebrate Morphology.

The Adams prize for an essay on the Theory of the Aber ration of Light has been divided between Mr. J. Larmor, F.R.S., Fellow of St. John's, and Mr. G. T. Walker, Fellow of Trinity, Senior Wranglers in 1880 and I 880 respectively.

The Smith's prizes for 1899 are adjudged to Mr. W. H. Austin and Mr. G. W. Walker, of Trinity, senior and fourth Wranglers respectively in 1897 . Mr. Frankland, of Clare, and Mr. Whipple, of Trinity, receive honourable mention.

Prof. Thomson announces a course of demonstrations in Physics, to be given in the Cavendish Laboratory during the Long Vacation, beginning July 5.
The Council of the Senate propose to expend $125 l$. in preparing an appropriate exhibit for the Educational Exhibitions to be held in London and in Paris in $\mathbf{I} 900$

The accommodation in the new chemical laboratory is already insufficient for the numbers seeking instruction, and it is accordingly proposed to expend $609 \mathrm{l}$. in adapting the attic story as an additional laboratory for elementary students.

The Senior Wranglership this year is divided between $\mathrm{Mr}$. G. Birtwistle, of Pembroke, and Mr. R. P. Paranjpye, of St. John's. Pembroke has had no Senior Wrangler since Sir George Stokes in 184r, and does well thus to mark the year of his jubilee as Lucasian Professor. Mr. Paranjpye is a Mahratta student, who gained numerous distinctions in the University of Bombay before coming to Cambridge: he is the first native of India who has attained the highest mathematical honours. There are forty names (including two ladies) in the list of Wranglers, indicating that the "year" is a strong one.

In Part II., Messrs. Hudson, of St. John's, and Cameron, of Caius, are alone in the First Class (first division). These were senior and second Wranglers respectively in 1898 . Miss F. E. Cave-Browne-Cave, of Girton, appears in the third division of the First Class.

In the Mechanical Sciences Tripos, Part I., six students have attained the First Class. In Part II. Mr. B. W. Hear, of Emmanuel, has the First Class to himself. Mr. H. E. Wimperis, of Caius, has in the same Tripos qualified for his degree as an "advanced student."

Mr. J. E. Marr, F.R.S., of St. John's, is appointed a member of the General Board of Studies, in place of Dr. Langley, resigned.

Dr. D. MacAlister, Mr. C. E. Grant, and Mr. C. Warburton are appointed members of the new Board of Agricultural Studies.

WE learn from Science that Dr. C. E. Beecher, professor of historical geography in Yale University, has been appointed to succeed the late Prof. O. C. Marsh as Curator of the geological collections of the Peabody Museum.

THE Education Department has received from Berne an announcement that an educational exhibition will be held in that city next autumn. The authorities organising the exhibition will welcome exhibits illustrating education in this country. Communications from those willing to take part in the exhibition should be addressed to the Director, Schweizerische Permanente Schulausstellung, Berne, from whom further particulars can be obtained.

WiTH a view to assisting teachers of schools and classes to acquaint themselves with the methods and principles of natural science, especially as bearing upon aspects of school and class work, the Technical Instruction Committee of the Liverpool City Council have made arrangements with Prof. W. A. Herdman, F.R.S., Professor of Zoology at University College, to give a short course of lectures and laboratory demonstrations on the study of natural history.

I'T has already been pointed out in these columns that the appointment of particular authorities to be responsible for technical and secondary education within their districts will reduce the overlapping which at present exists in many places. The London County Council was recently appointed as the sole authority to distribute the Science and Art grant in London, and as such it has taken exception to certain items of expenditure by the London School Board on technical or secondary education, on such lines as to compete injuriously with similar work in the Council's polytechnics and institutes in the same districts. The Times reports that the Local Government Board auditor has now ruled that such expenditure by the School Board is illegal, and can only be carried through as financial aid from the County Council. It is stated that the London School Board will appeal against this decision. Meantime, it is understood that the ruling wil! apply, not only to the Iondon Board, but also to other School Boards throughout the country.

SoME statistics relating to engineering education are given by Dr. M. E. Wadsworth in a paper published in the Transactions of the American Institute of Mining Engineers Enyineering education in the United States has been, on the whole, a thing of comparatively recent date-the pioneer schools being the Rensselaer Polytechnic Institute, established in I824; the Lit W. rence Scientific School, dating from 1846 ; and the Sheffield School, from 1847 . But little further prominent work was dune until 1863 , when the Columbia School of Mines was established and folluwed rapidly by numerous other engineering schools. 
The tables given by Dr. Wadsworth are not complete, but so far as they go they show that " in mining engineering the leading schools in the world, so far as shown from the records here published, are Freiberg, Leoben, Clausthal, Berlin, Paris, St. Etienne, Schemnitz, Przibram, Michigan College of Mines. California, Columbia, Lehigh, Massachusetts Institute of Technology, and Colorado."

AN account of the proposed Institute of Scientific Research for India, which Mr. J. M. Tata, of Bombay, has undertaken to endow with an annual income of a lakh and a quarter (125,000 rupees), is given by Sir Henry Acland in the second edition of his little volume, "Medical Missions in their Relation to Oxford" (London: Henry Frowde). As already announced, it is intended to found an institution which shall be, or correspond to, a Teaching University for India, concerning itself principally with post-graduate studies and scientific research. A committee has been organised to take the matter in hand and appeal for funds; and Mr. Tata's commissioner, Mr. B. J. Padshah, is making inquiries in Great Britain, in Europe, and in the United States, how best to carry out the scheme. Sir Henry Acland utilises the opportunity which the proposed scheme affords to accentuate his appeal that " a generous benefactor, or some great National Company, should complete in Oxford the Public Health Department for University Education in the subject of public health and anthropology, with special reference to Mr. Jamsetji M. Tata's great scheme for natural science in general, and sanitary science in particular, in India."

AN exhibition of practical work executed by candidates at the recent examinations of the City and Guilds of London Institute was opened at the Imperial Institute, on Friday, by the Duke of Devonshire. Referring to the character of the instruction given under the direction of this institute, His Grace remarked : The object of this instruction is to familiarise a student with all the processes and all the details the use of which is required in the trade he is going to undertake, and to show to him how the knowledge he has acquired in lectures or in books may be applied to the practical performance of his business. This exhibition, I hope, will help those who see it to realise the real. need of the technical instruction now being given. If you sent students direct from the classes of the Science and Art Department into a workshop they would be utterly incapable, in all probability, of applying in a practical way the knowledge which they have acquired in the classes. If you separate by too long an interval the lecture-room from the workshop, the work will be lost, but if you combine the lecture-room with the workshop, you have the material from which we may reasonably expect that expert finished artisans will be provided, although, of course, perfect workmen can only be produced by long and continuous practice. The artisan students in the registered classes of the institute now number over 34,000 , in addition to nearly 2000 students in its manual training classes, and of these numbers 13,800 were examined last year, showing an increase of 800 over any previous number.

\section{SOCIETIES AND ACADEMIES. LONDON.}

Royal Society, April 20.- "Note on the Fertility of different Breeds of Sheep, with Remarks on the Prevalence of Abortion and Barrenness therein." By Walter Heape, M.A., Trinity College, Cambridge. Communicated by W. F. R. Weldon, F.R.S.

The paper is a brief abstract of information obtained from 397 sheep-breeders, who have supplied records of flocks containing 122,673 ewes for the breeding season of $1896-7$.

The information obtained referred especially to the following eight pure breeds of sheep: Suffolk (7506 ewes), Kent (993I), Southdown (9134), Hampshire $(26,400)$, Oxford Down (3555), Dorset Horn (10,285), Shropshire (8492), Lincoln (17,880). Besides these, returns were received for a small number of flocks for each of ten other pure breeds, referred to below as "various pure breeds" (10,010), and for certain cross-bred flocks $(19,480)$.

Fertility. - The importance of fertility as a factor in the survival of a species is referred to, and some of the influences attending domestication which tend to reduce that importance are pointed out. Reference is made to Prof. Karl Pearson's account of the racial characteristic of fertility in the human No. I 546 , VoL. 6o] species, and it is demonstrated that, in spite of the equalising effects of domestication, fertility in different breeds of sheep is also of a racial character.

Owing to the fact that the returns supplied by flock-masters of the number of lambs born are admittedly not always correct, and in view of the fact that the record of twins produced is considerably more accurate, statistics of the latter have been chiefly utilised for generalisations regarding fertility. These records show that the pure breeds dealt with stand in the following order:-

Suffolk ( $52 \cdot 22$ per cent. of twins), Shropshire $(46 \cdot 84)$, Dorset Horn (37.55), Oxford Down $\left(35^{\circ} \mathrm{O} 2\right)$, Kent (31 38$)$, Lincoln $\left(29^{\circ} 09\right)$, various pure breeds (28.09), Hampshire (24.09), Southdown (18.67); that the average percentage of twins for these breeds is $30^{\circ} \mathrm{O} 2$; and that the cross-bred flocks produce $3 \mathrm{I}^{\circ} \mathrm{O} 4$ per cent. of twins.

From this return, it is seen that the value of the Suffolk and Shropshire breeds, as prolific breeds, is incontrovertible, while the records of the Southdowns is so low as to show urgent need for close attention to the subject on the part of breeders. It is to be noted that several of the pure breeds show a higher rate of fertility than the cross-bred flocks.

The fertility of certain of the pure breeds is then examined with regard to locality, and it is demonstrated that while locality may affect the fertility of a breed, it does not do so to a sufficient extent to alter the racial characteristic of the fertility of the breed. The chief possible exception to this is found among flocks of Lincoln sheep kept in Yorkshire, in which the percentage of twins recorded is practically double the percentage obtained in the home county ; but it is pointed out that, in this case, there are circumstances which indicate the difference is due to an abnormally low percentage of fertility in the Lincolnshire rather than to an especially high rate of fertility in the Yorkshire flocks.

The influence of management, of the condition, kind and amount of food available, of the season, weather, subsoil, and the age of breeding ewes upon the fertility of a fock was referred to.

Considering the percentage of lambs produced by the purebred flocks individually, it is seen that the percentage ranges, in 306 flocks, from 203.8 to $59^{\circ} 09$ per cent., the most frequent percentage being between I 10 and I 20 per cent.

As regards the different breeds, the most prominent points demonstrated by this inquiry are the value of the Suffolk breed from a point of view both of fertility and low rate of loss from abortion and barrenness; the unsatisfactory condition of Southdowns, both as regards fertility and loss; the urgent need for investigation of the fertility of Dorset Horn ewes with rams of their own breed; and of the conditions affecting both fertility and loss in flocks of Lincolns in the home county.

Physical Society, June 9.--Prof. Lodge, President, in the chair.-The Secretary read a paper, by Mr. C. G. Lamb, on the distribution of magnetic induction in a long iron bar. A Lowmoor iron rod, whose length was 250 times its diameter, was taken, and a $\mathrm{B}-\mathrm{H}$ curve plotted by ballistic measurements made with a search coil at the centre of the bar. The search coil was then moved along the bar, and the distribution of induction was determined for magnetising forces varying from $\mathrm{H}=\cdot 74$ to $\mathrm{H}=35^{\circ} \mathrm{O}$. Up to fields of 3.35 the induction leaks out more and more quickly as $\mathrm{H}$ increases, but above this value the induction tends to keep in more and more. From the curves obtained, the mean induction was deduced as well as the distance of the resultant pole from the middle of the bar. It is shown that this distance first decreases and then increases with the rise in field strength. According to the ellipsoidal theory, it should be constant. The bar was then made into a ring, and the $\mathrm{B}-\mathrm{H}$ curves again determined. From these curves, together with known relations between $B$, II and $\mu$, curves showing the variation of $\mu$ along the bar were constructed. The Chairman gave a general explanation of the way the leakage depended upon the permeability in the case of a long iron bar.-A paper on the absolute value of the freezing point was read by Mr. Rose-Innes. The corrected values of the absolute value of the freezing point determined by Lord Kelvin from experiments on hydrogen air and carbonic acid contain discrepancies amounting to $\mathrm{I} / 3$ per cent. between the carbonic acid and the hydrogen, while the separate measurements for carbonic acid ayree among themselves to about $\mathrm{I} / 6$ per cent. Starting with Lord Kelvin's equation for the forcing of a gas through a plug, the author has obtained a formula for the ab- 